\title{
Performance Assessment of Wastewater Treatment Plant of Hawassa St. George Brewery, Hawassa, Ethiopia
}

\section{FIREW, T; DANIEL F; *SOLOMON SS}

\begin{abstract}
Hawassa University, College of Natural and Computational Sciences, Department of Biology, Hawassa, P. O Box 493, Ethiopia
*Corresponding author Email: sorsasota@yahoo.com; Tel. $=+251916828248$

ABSTRACT: The aim of this study was to evaluate the performance efficiency of the wastewater treatment plant of Hawassa St. George brewery by collecting wastewater samples from the influent and outlet of each treatment unit and analyzed using standard methods for major physicochemical parameters. Results of the present study revealed that except for temperature $\left(36-38{ }^{\circ} \mathrm{C}\right)$, all of the other analyzed parameters of raw wastewater exceeded the national discharge limit indicating the necessity of treating the raw wastewater generated by the brewery. In most cases, the values decreased as the wastewater passed over the treatment units of the plant indicating an involvement of the units in the removal of pollutants. The brewery's treated final effluent had a mean value of $8.6 \pm 0.08(\mathrm{pH}), 24.9 \pm 0.6^{\circ} \mathrm{C}$ (temperature), $203.0 \mathrm{mg} / \mathrm{L}$ (COD), 17.7 $\mathrm{mg} / \mathrm{L}\left(\mathrm{NH}_{4}-\mathrm{N}\right), 3.62 \mathrm{mg} / \mathrm{L}\left(\mathrm{SO}^{2}{ }_{4}\right), 220.6 \mu \mathrm{S} / \mathrm{cm}(\mathrm{EC}), 49.8 \mathrm{mg} / \mathrm{L}\left(\mathrm{BOD}_{5}\right)$, and 529.6 NTU (turbidity), which were within national industrial wastewater discharge limits. However, the values of some parameters namely, TN $(41.0 \mathrm{mg} / \mathrm{L}), \mathrm{TP}(24.3$ $\mathrm{mg} / \mathrm{L}), \mathrm{H}_{2} \mathrm{~S}(3.1 \mathrm{mg} / \mathrm{L})$ and TDS $(110.6 \mathrm{mg} / \mathrm{L})$, were higher than the limits. The overall pollutant removal efficiency of the treatment plant was $96.0 \%$ (BOD), $92.3 \%$ (TSS), $92.0 \%$ (COD), $88.5 \%$ (EC), $80.6 \%$ (TDS), $49.6 \%$ (turbidity), $43.0 \%$ $\left(\mathrm{SO}_{4}{ }^{2-}\right), 42.7 \%\left(\mathrm{NH}_{4}-\mathrm{N}\right), 33.6 \%$ (temperature), 32.8\% $(\mathrm{TN}), 31.8 \%(\mathrm{pH})$, and $30.4 \%(\mathrm{TP})$. This result shows that the overall removal efficiency was higher only for $\mathrm{BOD}_{5}$, TSS, COD, TDS, and EC, all others (especially nutrients) had less than $50.0 \%$ efficiencies. Higher nutrient concentration exceeding the discharge limits in final effluent and poor removal efficiency of the treatment plant indicates that the Hawassa St. Gorge brewery waste treatment plant is not effective enough to lower concentrations of these parameters below the discharge limit. Therefore, in order to make the plant more efficient and to reduce the effect of effluent, the factory should take some technological, technical and recycling measures.
\end{abstract}

\section{DOI: https://dx.doi.org/10.4314/jasem.v22i8.23}

Copyright: Copyright (C) 2018 Firew et al. This is an open access article distributed under the Creative Commons Attribution License (CCL), which permits unrestricted use, distribution, and reproduction in any medium, provided the original work is properly cited.

Dates: Received: 11 July 2018; Revised: 31July: 2018; Accepted: 21 August 2018

Keywords: Brewery, Hawassa, Performance, St. George, Treatment, Wastewater

Even though substantial technological improvements have been made in the past, it has been estimated that approximately 3 - $10 \mathrm{~L}$ of wastewater is generated per liter of beer produced in breweries (Kanagachandran and Jayaratne, 2006).According to Alebel (2014), in Ethiopia, $90 \%$ of the industries are releasing their effluents into water bodies, streams, and land without any treatment mechanisms. Moreover, EEPA (2003) stated that most of the effluent discharged by industries including breweries in Ethiopia, does not meet the national discharge standards as many of them release their effluent with little or no prior treatment. The principal objective of any wastewater treatment is generally to allow industrial effluents to be disposed of without danger to human health or unacceptable damage to the natural environment. Because the treated effluent from the factory is released to the immediate surrounding with residences and surface waters (the stream, river, and lake), there is a need to ensure its safety to human health and the environment. Furthermore, because the factory is relatively younger, the performance efficiency of the treatment plant and the chemical composition of the effluent discharged to the surrounding have not been studied. Therefore, the main objective of this study was to evaluate the composition of the effluent and overall pollutants removal performance of the wastewater treatment plant of Hawassa St. George Brewery.

\section{MATERIALS AND METHODS}

Description of the Study Area: The study was conducted at St. George Brewery in Hawassa city, Southern Ethiopia. Hawassa city is on the shores of Lake Hawassa in the Great Rift Valley located $275 \mathrm{~km}$ south of Addis Ababa. It has latitude and longitude of $7^{\circ} 3^{\prime} \mathrm{N}$ and on an elevation of 1708 meters above sea level. The brewery officially started production in June 2011 and is located in Cheffe-Kotijewesa Keble, in Tula sub-city, southeast part of Hawassa city in the industrial zone between Moha soft drink factory and Hawassa textile factory, GPS (UTM), Northing 777,012 and Easting 445,589, on altitude 1,713meters above sea level. The annual production capacity of the brewery is approximately 1,040,250 hectoliter of the bottled brand and drought beers. 
Wastewater Sampling Methods: Before sampling, the plastic sample bottles cleaned thoroughly using a detergent, $1: 1 \mathrm{HCl}$, triple rinsed with distilled water and during sampling the bottles were triple rinse with the wastewater as suggested by Fatoki and Mathabatha (2001). The Wastewater Treatment Plant (WWTP) of the brewery consists of four main units namely: influent tank, equalization (buffer), anaerobic effluent tank (UASB reactor) and post-aeration tank. The samples were taken at the inlet point of the raw wastewater and an outlet of each treatment unit and at the final discharge point of the treatment plant using 1 L polypropylene bottles from April 2016 to September 2016. Considering the variability of nature of brewery effluent, a snap sampling method was used, and five round (twenty-five) samples of wastewater were taken for the analysis of the selected physicochemical parameters.

Physicochemical Parameters Analysis Methods: Before any analysis of samples, instruments were calibrated using standard solutions. Determinations of the parameters were done according to the analytical methods described in Standard Methods for the Examination of Wastewater (APHA, 2005), using graded laboratory reagents. For all the methods that required the use of the spectrophotometer, both reagent blanks and sample blanks were used.

The PH, temperature Total Dissolved Solid (TDS) and conductivity (EC) of the samples were measured insitu and Nitrate-nitrogen $\left(\mathrm{NO}_{3}{ }^{-} \mathrm{N}\right)$, Nitrite nitrogen $\left(\mathrm{NO}_{2}-\mathrm{N}\right)$, Ammonium Nitrogen $\left(\mathrm{NH}_{4}{ }^{-}-\mathrm{N}\right.$, Orthophosphate $\left(\mathrm{PO}_{4}{ }^{3-}\right)$, Hydrogen Sulfide $\left(\mathrm{H}_{2} \mathrm{~S}\right)$ and sulfate $\left(\mathrm{SO}_{4}{ }^{2-}\right)$ were determined using spectrophotometer (HACH DR/5000 Model, Loveland, CO, USA) according to manufacturer's instructions. The TSS was determined by the gravimetric method at a temperature of $103-105{ }^{\circ} \mathrm{C}$ according to standard methods of APHA (2005).

The Biological Oxygen Demand (BOD) which is expressed as weight of oxygen consumed per unit volume of water during a defined period (5 days) at a defined temperature $\left(20^{\circ} \mathrm{C}\right)$ was calculated following the method of Hamer (1986) and was determined as the difference between initial oxygen concentration in sample and concentration after 5 days incubation in BOD bottles at $20^{\circ} \mathrm{C}$. The Chemical Oxygen Demand (COD) was determined by colorimetric determination method using $\mathrm{HACH}$ spectrophotometer $(\mathrm{HACH}$ DR/5000 Model, Loveland, CO, USA).

Pollutants Removal Efficiency Determination Method: Pollutant removal efficiency of each treatment unit of the plant was evaluated from the difference in pollutants concentration in the influent and effluent from each unit, using the following formula (Enitan et al., 2015).

\section{Removal Efficiency $(\%)=[(\mathrm{Ci}-\mathrm{Ce}) / \mathrm{Ci}]$ x 100}

Where, $\mathrm{Ci}=$ is the concentration of the pollutants in the influent; $\mathrm{Ce}=$ is the concentration of the pollutants in the effluent.

Data Analysis: The data obtained were analyzed using appropriate statistical tools: Excel spreadsheet and statistical software using Microsoft Excel and SPSS version 16, respectively. One-way ANOVA was performed to assess whether there is a significant difference in the quality of the parameters at every stage of the treatment, significance test was performed at alpha $=0.05$. Furthermore, the results from the analysis of physicochemical parameters of the final effluent were compared with recommended industrial discharge limit set by EEPA (2003).

\section{RESULTS AND DISCUSSION}

Characteristics of the Raw Wastewater: The determined EC, TDS and turbidity values in this study ranged from 1900.0 to $1921.0 \mu \mathrm{S} / \mathrm{cm}, 950.0$ to 961.0 $\mathrm{mg} / \mathrm{L}$ and 850 to $1110.0 \mathrm{NTU}$, respectively (Table 1 ). These values are within the wider ranges reported for some brewery raw wastewater by Yared (2008) and Kebena (2014). The TSS concentration ranged from 510.0 to $680.0 \mathrm{mg} / \mathrm{L}$ with an average value of $606.3 \mathrm{mg} / \mathrm{L}$ (Table 1) and this was found within the range reported by Driessen et.al (2003) and Kebena (2014) for Addis Ababa St. George Brewery in Ethiopia. As described by Brewers of Europe (2002) and Driessen et.al. (2003), brewing activities like malt processing and filtration could be the cause for the high TSS values, which indicated that brewery solids mainly of spent grains, Kieselguhr, surplus yeast, cold break and possible label pulp from the bottle washer.

Brewery raw wastewater had COD value ranging from $2510.0 \mathrm{mg} / \mathrm{L}$ to $2617.0 \mathrm{mg} / \mathrm{L}$ with the average of $2565.7 \mathrm{mg} / \mathrm{L}$ (Table 1 ). This COD value was within the range reported by Kebena (2014) (1750 mg/L to 2800 $\mathrm{mg} / \mathrm{L}$ ) and Driessen, et.al, (2003) (2000 mg/l to 6000 $\mathrm{mg} / \mathrm{L}$ ). The obtained $\mathrm{BOD}_{5}$ value ranged from 1303 $\mathrm{mg} / \mathrm{L}$ to $1620 \mathrm{mg} / \mathrm{L}$ with the average value $1460 \mathrm{mg} / \mathrm{L}$ ) (Table 1) and it was found that $1331 \mathrm{mg} / \mathrm{L}$ to 1991 $\mathrm{mg} / \mathrm{L}$ and $1200 \mathrm{mg} / \mathrm{L}$ to $3,600 \mathrm{mg} / \mathrm{L}$, respectively, was reported by the same authors. As indicated by Enitan et al. (2015), the trends and variability of the values plus large standard deviations from the means shows that the pollution level of the raw wastewater is high. Therefore, the observed high value of standard 
deviation of BOD seems to be due to the variability of brewery wastewater composition.

According to the Brewers of Europe (2002), the high organic loads in the raw wastewater arise from dissolved carbohydrates, the alcohol from beer wastes, and a high content of suspended solids, such as spent grain, malt, and yeast. It is also explained that the raw materials like malt and adjuncts, and the discharge of trub, weak wort, surplus yeast, emptying and rinsing of process tanks, pre and after- runs of Kieselguhr filtration and drip beer could possibly be the sources of high COD and $\mathrm{BOD}_{5}$ in the wastewater. Brewers of Europe (2002) also noted that organic components in brewery effluent which have BOD5/COD ratio of 0.6 to 0.7 are generally easily biodegradable. The present results indicated that the BOD5/COD ratio was nearly 0.6 (0.57), which is indicative of easily biodegradability nature of organic matter in the raw wastewater.

Results of nutrient load analysis of wastewater (Table 1) showed that the average concentrations of $\mathrm{TN}$, $\mathrm{NH} 4-\mathrm{N}$ and TP were $61.0 \mathrm{mg} / \mathrm{L}, 30.9 \mathrm{mg} / \mathrm{L}$ and 34.9 $\mathrm{mg} / \mathrm{L}$, respectively, and these values were in the range reported by Yared Shumate (2008) and Kebena (2014). According to Brewers of Europe (2002) and Driessen et.al. (2003), the raw materials malt and adjuncts, the nitric acid used for cleaning and the amount of spent yeast present could be the sources of nitrogen in the wastewater. Therefore, sources of the nitrogen forms could be malt processing followed by protein hydrolysis into NH4-N and NO3-N. Also, it might have come from dissociation of the nitric acid used in the Cleaning-In-Place (CIP) units as well as ammonification and nitrification of the ammonium nitrogen in the wastewater during the periods of sample collection for analysis. Furthermore, the average concentrations of $\mathrm{SO}_{4}{ }^{2-}$ and $\mathrm{H}_{2} \mathrm{~S}$ ranged were $6.4 \mathrm{mg} / \mathrm{L}$ and $0.6 \mathrm{mg} / \mathrm{L}$, respectively (Table 1 ). The $\mathrm{pH}$ values of wastewater ranged from 12 to $13 \mathrm{pH}$ units which were within the wide range (2-12) $\mathrm{pH}$ values given by Driessen et.al. (2003) for the discharges from different sections of a brewery. But Kebena (2014) reported a narrow range of $\mathrm{pH}(6.2$ to 11.8$)$ and this variation could be attributed to the batch processing nature of the brewery and the amount and type of chemicals (e.g. caustic soda, phosphoric acid, nitric acid, etc.) used at the CIP units.

In general, results (Table 1) of the present study revealed that except for temperature $\left(36-38{ }^{\circ} \mathrm{C}\right)$, all of the other analyzed physicochemical parameters values of raw wastewater exceeded the discharge limit set by EEPA (2003). Moreover, the raw effluent produced from the brewery did not meet the discharge limit for wastewater disposal to water bodies according to the European Union (EU) discharge limits (Driessen and Vereijken, 2003). Therefore, for better environmental protection, the raw wastewater needs to be treated at an acceptable level using efficient treatment system before it is discharged to the environment.

Physicochemical Characteristics and Performance Efficiency of Each Treatment Unit: Before the treated effluent of the factory is released into the surrounding environment, the wastewater passes through four series of treatment units of the WWTP system arranged in the order of influent tank, equalization tank, anaerobic effluent tank (UASB reactor) and post aeration tank. The recorded physicochemical parameters values of each treatment unit (after their respective retention time) are depicted in Table 2 . The trend of values of nine parameters (COD, BOD5, TSS, $\mathrm{TN}, \mathrm{SO}_{4}{ }^{2-}, \mathrm{H} 2 \mathrm{~S}, \mathrm{TP}$, turbidity and temperature) showed a continuous decrease as the wastewater passed through the four units. Pollutant removal of each of the treatment unit is described below.

Influent Tank Removal Efficiency: Large particles, fat, oil and grease are removed by the coarse screen and a static oil trap that is installed at the inlet of the WWTP and then the brewery wastewater is collected in the influent pump pit tank in which it is retained for about 5 minutes. Comparison of the mean value of the parameters in the raw effluent with that in an effluent from the influent tank indicated (Table 2) a significant difference $(p<0.05)$ only for the parameters such as EC, Turbidity and $\mathrm{H}_{2} \mathrm{~S}$. The recorded average removal efficiencies of influent tank was $37.54 \%$ for $\mathrm{SO}_{4}{ }^{2-}$, $22.93 \%$ (TDS), $22.9 \%$ (EC), $7.07 \%$ (turbidity), $4.90 \%$ (TN), $4.01 \%$ (TP), $2.4 \%$ (temperature), $0.75 \%$ (BOD 5 ), $0.71 \%$ (TSS), $0.65 \%$ (COD), $0.47 \%$ (PH) and $-10.7 \%\left(\mathrm{NH}_{4}-\mathrm{N}\right)$ (Table 3). Kebena (2014) reported higher removal efficiencies for Addis Ababa St. Gorge brewery than the present study for $\mathrm{BOD}_{5}(1.67 \%)$, TSS (19.64\%), COD (5.28\%) and $\mathrm{NH}_{4}-\mathrm{N}(1.98 \%)$, and lower efficiencies for TDS (3.05\%), TN (1.29\%), and TP $(0.52 \%)$. Results (Table 2$)$ of the present study revealed that the concentration of $\mathrm{NH}_{4}-\mathrm{N}$ was increased above that in raw wastewater (from $30.9 \pm 7$ to $34.2 \pm 8.4 \mathrm{mg} / \mathrm{L}$ ) and consequently decreased in removal efficiency (Table 3). As described by Gerardi (2002), the increment of $\mathrm{NH}_{4}-\mathrm{N}$ concentration may be associated with the reduction (de-nitrification) process of $\mathrm{NO}_{3}-\mathrm{N}$ into $\mathrm{NH}_{4}-\mathrm{N}$ by anaerobic bacteria.

Equalization (Buffer) Tank Removal Efficiency: Before it enters into the UASB reactor, the raw wastewater passes over a static fine screen for mechanical pre-treatment in order to reduce the 
amount of suspended solids. Comparison of the average values of effluent from the influent tank with that of the equalization tank showed a significant decrease in pollutants $(\mathrm{p}<0.05)$ only for TDS TSS, $\mathrm{pH}$ and $\mathrm{NH}_{4}-\mathrm{N}$ (Table 2). The average removal efficiencies of the tank was $38.85 \%(\mathrm{PH}), 28.5 \%$ (TSS), $19.02 \%$ (TDS), $18.9 \%$ (EC), $10.3 \%$ (turbidity), $3.5 \%$ (temperature), $2.7 \%\left(\mathrm{BOD}_{5}\right.$ ), $2.4 \%$ (TP), $1.16 \%$ (COD), $-9.6 \%\left(\mathrm{NH}_{4}-\mathrm{N}\right)$ and $-30.0 \%\left(\mathrm{SO}_{4}{ }^{2-}\right)$ (Table 3$)$. Kebena (2014) reported relatively higher removal efficiencies of equalization tank for Addis Ababa brewery than the present study for COD, $\mathrm{BOD}_{5}, \mathrm{SO}^{2-}{ }_{4}$ and $\mathrm{TP}$ and $\mathrm{NH}_{4}-\mathrm{N}$, but lower efficiencies for TSS and TDS.

Results of the present study revealed that after treatment in equalization tank, the concentration of $\mathrm{NH}_{4}-\mathrm{N}$ was still increased above that recorded for the influent tank (from 34.2 to $37.5 \mathrm{mg} / \mathrm{L}$ ) (Table 2) resulting in a decrease in its removal (Table 3). According to Larisa (2008), such decrease in ammonium removal could be related to the involvement of nitrate-reducing bacteria in anaerobic digestion that reduces $\mathrm{NO}_{3}{ }^{-}$into ammonium $\left(\mathrm{NH}_{4}{ }^{+}\right)$. In addition, there was a decreased in $\mathrm{SO}_{4}{ }^{2-}$ removal efficiency of the equalization tank and as suggested by Sperling (2007), this may be due to the hydrolysis of protein-based large molecules and complex organic molecules into sugar and amino acids.

According to Gerargi (2003), the concentrations of macronutrients such as phosphate and nitrogen are estimated in relation to COD present in the wastewater. It is also recommended that the ratio of COD: $\mathrm{N}$ : $\mathrm{P}$ should be maintained at 350: 5: 1, since a deficiency of some of these nutrients in the wastewater may cause a deficiency in the growth of the bacteria involved. The results obtained in this study revealed that the ratio of COD: $\mathrm{N}$ : $\mathrm{P}$ was $77: 1.7: 1$, indicating there was still higher concentration of nutrients in the wastewater that is released from equalization tank and entering to the proceeding biological treatment unit (UASB reactor).

According to Stephenson and Blackburn (1998), an increase in the organic concentrations can be explained by the fact that the lime used in $\mathrm{pH}$ correction could have also acted as coagulants, thereby improving the settling properties of the solids. According to Spellman (2003), the $\mathrm{BOD}_{5}$ removed efficiency of primary effluent treatment plant should be $25-35 \mathrm{mg} / \mathrm{L}$. However, the result (Table 2) obtained from this study was found to be $40 \mathrm{mg} / \mathrm{L}$, which shows the effectiveness of the primary effluent treatment units.
Anaerobic Effluent Tank (UASB reactor) Removal Efficiency: Pre-treated wastewater is fed into UASB reactor, where most biological treatment expected to takes place. The retention time in the UASB reactor was 6 hours. After the wastewater passed over the UASB reactor, the values of most pollutants decreased and comparisons of the mean value measured in this unit with equalization tank indicated significant differences $(\mathrm{p}<0.05)$ for EC, TDS, TSS and turbidity (Table 2). The high $\mathrm{BOD}_{5}(94.6 \%)$, COD $(91.2 \%)$ and TSS (78.9\%) removal efficiencies recorded (Table 3) in the UASB reactor of Hawassa brewery is almost consistent with that reported by Kebena (2014) for Addis Ababa brewery and also it is within the ranges that reported by Sharda et.al. (2013) for M/s Carlsberg India Ltd brewery industry in India. The high BOD and COD removal efficiencies of UASB reactor observed in this study may be due to properly kept operational parameters of the reactor and its organic loading rates. The BOD/COD ratio ranges from 0.3-0.4 due to the fluctuations in inflows, quantity and quality of the effluent and is a function of various processes like brewing, fermentation and clarification, etc. Although settleable solids are often a problem in breweries, as described by (Sharda et.al. (2013), the observed TSS removal efficiencies of $78.9 \%$ (Table 3) may be attributed to the higher Volatile Suspended Solids (VSS) resulting in the formation of granular sludge bed in the UASB reactor.

Similarly, high removal efficiencies of $80.84 \%$ and $80.8 \%$ were recorded in this study (Table 3 ) for EC and TDS, respectively and this is much higher than the $28.94 \%$ (EC) and $26.28 \%$ (TDS) reported by Kebena (2014) for Addis Ababa brewery. These high removal efficiencies may be due to the proper functioning of the reactor. Relatively lower removal efficiencies were recorded for nutrients such as TP $(20.2 \%), \mathrm{SO}_{4}{ }^{2-}$ (19.2\%), $\mathrm{NH}_{5}-\mathrm{N}(14.7 \%)$ and $\mathrm{TN}(14.3 \%)$ (Table 3). However, these are higher than the $1.45 \%, 5.86 \%$, $9.5 \%$ and $1.92 \%$, respectively, reported by Kebena (2014). Moreover, the treatment efficiency of the UASB reactor obtained in this study was $38.85 \%$, $10.7 \%$ and $10.3 \%$ for $\mathrm{pH}$, temperature and turbidity, respectively (Table 3 ).

Post Aeration Tank Removal Efficiency: After treatment in UASB reactor, the anaerobic effluent flows to the post-aeration tank where it is post-aerated in order to remove odor compounds mainly $\mathrm{H}_{2} \mathrm{~S}$ from the anaerobic effluent and further reduction of organic matter. Comparisons of mean differences of pollutant in an effluent from UASB reactor with effluent from the post-aeration tank reactor, there were significant differences $(\mathrm{p}<0.05)$ for TSS, temperature and $\mathrm{NH}_{4}-\mathrm{N}$ (Table 2). 
Table 1: Physicochemical characteristics of brewery raw wastewater

\begin{tabular}{llll}
\hline Parameters & Units & Mean \pm SD & Range \\
\hline $\mathrm{EC}$ & $\mu \mathrm{S} / \mathrm{cm}$ & $1909.6 \pm 9.3$ & $1900-1921$ \\
$\mathrm{TDS}$ & $\mathrm{mg} / \mathrm{L}$ & $955 \pm 4.9$ & $950-961$ \\
$\mathrm{TSS}$ & $\mathrm{mg} / \mathrm{L}$ & $606.3 \pm 83.3$ & $510-680$ \\
Turbidity & $\mathrm{NTU}$ & $1049.8 \pm 112$ & $850-1110$ \\
$\mathrm{pH}$ & $\mathrm{pH}$ unit & $12.6 \pm 0.08$ & $12-13$ \\
$\mathrm{Temperature}$ & ${ }^{\circ} \mathrm{C}$ & $37.5 \pm 0.79$ & $36-38$ \\
$\mathrm{COD}$ & $\mathrm{mg} / \mathrm{L}$ & $2565.7 \pm 53.6$ & $2510-2617$ \\
$\mathrm{BOD}$ & $\mathrm{mg} / \mathrm{L}$ & $1460 \pm 157.6$ & $1305-1620$ \\
$\mathrm{TN}$ & $\mathrm{mg} / \mathrm{L}$ & $61 \pm 3.9$ & $49-65$ \\
$\mathrm{NH}_{4}-\mathrm{N}$ & $\mathrm{mg} / \mathrm{L}$ & $30.9 \pm 7.1$ & $21-40$ \\
$\mathrm{NO}_{3}-\mathrm{N}$ & $\mathrm{mg} / \mathrm{L}$ & $24.8 \pm 1.6$ & $24-27$ \\
$\mathrm{NO}_{2}-\mathrm{N}$ & $\mathrm{mg} / \mathrm{L}$ & $17.3 \pm 5.3$ & $13-26$ \\
$\mathrm{TP}^{2-}$ & $\mathrm{mg} / \mathrm{L}$ & $34.9 \pm 3.6$ & $32-40$ \\
$\mathrm{SO}_{4}{ }^{2-}$ & $\mathrm{mg} / \mathrm{L}$ & $6.4 \pm 1.8$ & $4-8$ \\
$\mathrm{H}_{2} \mathrm{~S}$ & $\mathrm{mg} / \mathrm{L}$ & $0.6 \pm 0.1$ & $0.3-0.9$ \\
\hline & & & \\
\hline
\end{tabular}

Table 2. Physicochemical characteristics of the wastewater at each treatment units

\begin{tabular}{lllll}
\hline Parameters & \multicolumn{4}{l}{ Values (Mean \pm SD) in each unit } \\
\cline { 2 - 5 } & $\begin{array}{l}\text { Influent } \\
\text { Tank } \\
\text { Effluent }\end{array}$ & $\begin{array}{l}\text { Equalization } \\
\text { Tank Effluent }\end{array}$ & $\begin{array}{l}\text { UASB } \\
\text { Reactor } \\
\text { Effluent }\end{array}$ & $\begin{array}{l}\text { Aeration } \\
\text { Tank } \\
\text { Effluent }\end{array}$ \\
\hline $\mathrm{EC}(\mu \mathrm{S} / \mathrm{cm})$ & $1471.6 \pm 429.6^{\mathrm{b}}$ & $1192.8 \pm 222.4^{\mathrm{b}}$ & $228.6 \pm 4.9^{\mathrm{c}}$ & $220.6 \pm 1.1^{\mathrm{c}}$ \\
$\mathrm{TDS}(\mathrm{mg} / \mathrm{L})$ & $736 \pm 214.9^{\mathrm{a}}$ & $596 \pm 110.7^{\mathrm{b}}$ & $114.4 \pm 2.5^{\mathrm{c}}$ & $110.6 \pm 0.6^{\mathrm{c}}$ \\
$\mathrm{TSS}(\mathrm{mg} / \mathrm{L})$ & $602 \pm 85.8^{\mathrm{a}}$ & $430.7 \pm 53.8^{\mathrm{b}}$ & $90.7 \pm 5.5^{\mathrm{c}}$ & $46.7 \pm 5.7^{\mathrm{d}}$ \\
$\mathrm{Turbidity}(\mathrm{NTU})$ & $870.6 \pm 44.95^{\mathrm{b}}$ & $780.8 \pm 0.8^{\mathrm{b}}$ & $622 \pm 61.8^{\mathrm{c}}$ & $529.6 \pm 9^{\mathrm{c}}$ \\
$\mathrm{pH}$ & $12.56 \pm 0.2^{\mathrm{a}}$ & $7.7 \pm 0.1^{\mathrm{b}}$ & $7.9 \pm 0.35^{\mathrm{b}}$ & $8.6 \pm 0.08^{\mathrm{b}}$ \\
$\mathrm{Temperature}\left({ }^{\circ} \mathrm{C}\right)$ & $36.7 \pm 0.3^{\mathrm{a}}$ & $35.4 \pm 0.4^{\mathrm{a}}$ & $31.6 \pm 3.4^{\mathrm{a}}$ & $24.9 \pm 0.6^{\mathrm{b}}$ \\
$\mathrm{COD}(\mathrm{mg} / \mathrm{L})$ & $2548.3 \pm 56^{\mathrm{a}}$ & $2518.7 \pm 61.8^{\mathrm{a}}$ & $222 \pm 15.7^{\mathrm{b}}$ & $203 \pm 15.7^{\mathrm{b}}$ \\
$\mathrm{BOD}_{5}(\mathrm{mg} / \mathrm{L})$ & $1449 \pm 158.7^{\mathrm{a}}$ & $1409.7 \pm 160^{\mathrm{a}}$ & $75.7 \pm 6.7^{\mathrm{b}}$ & $49.8 \pm 17^{\mathrm{b}}$ \\
$\mathrm{T}(\mathrm{mg} / \mathrm{L})$ & $58 \pm 4.5^{\mathrm{a}}$ & $56 \pm 3.9^{\mathrm{a}}$ & $48 \pm 6.3^{\mathrm{b}}$ & $41 \pm 7.2^{\mathrm{b}}$ \\
$\mathrm{NH}_{4}-\mathrm{N}(\mathrm{mg} / \mathrm{L})$ & $34.2 \pm 8.4^{\mathrm{a}}$ & $37.5 \pm 5.8^{\mathrm{b}}$ & $32 \pm 9.5^{\mathrm{a}}$ & $17.7 \pm 6.9^{\mathrm{c}}$ \\
$\mathrm{TP}(\mathrm{mg} / \mathrm{L})$ & $33.5 \pm 3.7^{\mathrm{a}}$ & $32.7 \pm 5^{\mathrm{a}}$ & $26.10 \pm 1.9^{\mathrm{b}}$ & $24.3 \pm 1.4^{\mathrm{b}}$ \\
$\mathrm{SO}_{4}{ }^{2-}(\mathrm{mg} / \mathrm{L})$ & $4.0 \pm 1.23^{\mathrm{a}}$ & $5.2 \pm 3.1^{\mathrm{a}}$ & $4.2 \pm 2.2^{\mathrm{b}}$ & $3.62 \pm 2.1^{\mathrm{b}}$ \\
$\mathrm{H}_{2} \mathrm{~S}(\mathrm{mg} / \mathrm{L})$ & $1.96 \pm 0.6^{\mathrm{b}}$ & $2.0 \pm 0.23^{\mathrm{b}}$ & $3.02 \pm 0.3^{\mathrm{c}}$ & $3.1 \pm 0.26^{\mathrm{c}}$ \\
\hline \multicolumn{4}{c}{ Note: Values with different superscript are significantly different at alpha 0.05} \\
\end{tabular}

Table 3: Pollutant Removal Efficiency of each treatment unit of the system

\begin{tabular}{lllll}
\hline Parameters & \multicolumn{4}{l}{ Removal Efficiency (Percentage) of each unit } \\
\cline { 2 - 5 } & $\begin{array}{l}\text { Influent } \\
\text { Tank }\end{array}$ & $\begin{array}{l}\text { Equalization } \\
\text { Tank }\end{array}$ & $\begin{array}{l}\text { UASB } \\
\text { Reactor }\end{array}$ & $\begin{array}{l}\text { Aeration } \\
\text { Tank }\end{array}$ \\
\hline $\mathrm{EC}(\mu \mathrm{S} / \mathrm{cm})$ & 22.9 & 18.9 & 80.84 & 3.5 \\
$\mathrm{TDS}(\mathrm{mg} / \mathrm{L})$ & 22.93 & 19.02 & 80.8 & 3.3 \\
$\mathrm{TSS}(\mathrm{mg} / \mathrm{L})$ & 0.71 & 28.5 & 78.9 & 48.5 \\
$\mathrm{Turbidity}(\mathrm{NTU})$ & 17.07 & 10.3 & 10.3 & 14.8 \\
$\mathrm{pH}$ & 0.47 & 38.85 & 32.29 & -8.9 \\
$\mathrm{Temperature}\left({ }^{\circ} \mathrm{C}\right)$ & 2.1 & 3.5 & 10.7 & 21.2 \\
$\mathrm{COD}(\mathrm{mg} / \mathrm{L})$ & 0.65 & 1.16 & 91.2 & 8.6 \\
$\mathrm{BOD}_{5}(\mathrm{mg} / \mathrm{L})$ & 0.75 & 2.7 & 94.6 & 34.2 \\
$\mathrm{TN}(\mathrm{mg} / \mathrm{L})$ & 4.9 & 3.45 & 14.3 & 14.6 \\
$\mathrm{NH}_{4}-\mathrm{N}(\mathrm{mg} / \mathrm{L})$ & -10.7 & -9.6 & 14.7 & 44.7 \\
$\mathrm{NO}_{3}-\mathrm{N}(\mathrm{mg} / \mathrm{L})$ & 3.35 & 0.05 & 3.6 & 9.9 \\
$\mathrm{NO}_{2}-\mathrm{N}(\mathrm{mg} / \mathrm{L})$ & 13.3 & -1.3 & 38.16 & 41.5 \\
$\left.\mathrm{TP}{ }^{2} \mathrm{mg} / \mathrm{L}\right)$ & 4.01 & 2.4 & 20.2 & 6.9 \\
$\mathrm{SO}_{4}{ }^{2-}(\mathrm{mg} / \mathrm{L})$ & 37.54 & -30 & 19.2 & 13.8 \\
$\mathrm{H}_{2} \mathrm{~S}(\mathrm{mg} / \mathrm{L})$ & -2.2 & -0.2 & -50 & -3.3 \\
\hline
\end{tabular}

The percentage treatment efficiency of the aeration tank was $48.5 \%$ for TSS, 44.7\% ( $\left.\mathrm{NH}_{4}-\mathrm{N}\right), 38.6(\mathrm{COD}), 34.2 \%\left(\mathrm{BOD}_{5}\right), 21.2 \%$ (temperature), $14.8 \%$ (turbidity), $14.6 \%$ (TN), $13.8 \%\left(\mathrm{SO}^{2-}\right), 6.9 \%$ (TP), $3.5 \%$ (EC), $3.3 \%$ (TDS), and $-8.9 \%(\mathrm{pH})$ in decreasing order (Table 3 ). The removal of sulfate was insignificant (Table 3 ) and the removal decreased in the aeration tank. The reason for this seems to be due to oxygen input, in which $\mathrm{SO}^{2-}$ oxidized to $\mathrm{SO}^{2-}{ }_{4}$ and increased the concentration of $\mathrm{SO}^{2-}$ 4 , which leads to decreases in the percentage removal efficiency of $\mathrm{SO}_{4}^{2-}$

Physicochemical Characteristics of Final Effluent and Overall Removal Efficiency: The brewery final effluent had a mean value of $8.6 \pm 0.08 \quad(\mathrm{pH}), \quad 24.9 \pm 0.6^{\circ} \mathrm{C}$ (temperature), $203.0 \mathrm{mg} / \mathrm{L}$ (COD), $17.7 \mathrm{mg} / \mathrm{L} \quad\left(\mathrm{NH}_{4}-\mathrm{N}\right), 3.62 \mathrm{mg} / \mathrm{L}$ $\left(\mathrm{SO}^{2-}{ }_{4}\right), 46.7 \mathrm{mg} / \mathrm{L}$ (TSS), 220.6 $\mu \mathrm{S} / \mathrm{cm}$ (EC), $49.8 \mathrm{mg} / \mathrm{L}\left(\mathrm{BOD}_{5}\right)$, and 529.6 NTU (turbidity) (Table 4), which were within the set discharge limits of EEPA (2003).

However, the mean concentrations of some nutrient namely, TN (41.0 $\mathrm{mg} / \mathrm{L})$, TP (24.3 mg/L), $\mathrm{H}_{2} \mathrm{~S}$ (3.1 $\mathrm{mg} / \mathrm{L})$ and TDS (110.6 mg/L), were higher than the acceptable national discharge limits (EEPA, 2003).The mean values of final effluent recorded in this study for $\mathrm{EC}, \mathrm{COD}$, $\mathrm{BOD}_{5}, \mathrm{TN}, \mathrm{SO}_{4}^{2-}, \mathrm{TDS}, \mathrm{TSS}$ and temperature were lower than that reported by Kebena (2014) for Addis Ababa St. Gorge brewery.

Therefore, the present study revealed that pollutants removal efficiency of Hawassa brewery for the above mentioned eight parameters is higher indicating better treatment performance. However, for $\mathrm{TP}, \mathrm{NH}_{4}-\mathrm{N}$ and $\mathrm{pH}$ the removal efficiency recorded in this study was lower than the findings of Kebena (2014).

The average influent $\mathrm{TN}$ and $\mathrm{NH} 4-$ $\mathrm{N}$ concentrations were $41.0 \mathrm{mg} / \mathrm{L}$ and $34.2 \mathrm{mg} / \mathrm{L}$, respectively. The percentage removal efficiency of the treatment system for $\mathrm{TN}$ and $\mathrm{NH} 4-$ $\mathrm{N}$ were $32.8 \%$ and $42.7 \%$, respectively (Table 4) indicating low removal efficiency. 
According to Larisa (2008), low removal of nutrient is expected in anaerobic systems and a possible reason for this is that organic nitrogen is hydrolyzed to ammonia, which is not removed by anaerobic processes and consequently, their concentration increases in the liquid phase. This also might be the reason for the TN concentration slightly above the provisional discharge limit (40 mg/L) of EEPA (2003). Low COD input to the post-aeration tank could also increase nitrification efficiency.

Table 4: Overall Pollutant removal efficiency of the treatment plant

\begin{tabular}{|c|c|c|c|c|}
\hline \multirow[t]{2}{*}{ Parameters } & \multicolumn{2}{|c|}{ Values $($ Mean \pm SD $)$} & \multirow{2}{*}{$\begin{array}{l}\text { Overall removal } \\
\text { efficiency }(\%)\end{array}$} & \multirow{2}{*}{$\begin{array}{l}\text { EEPA (2003) } \\
\text { discharge } \\
\text { limits }\end{array}$} \\
\hline & $\begin{array}{l}\text { Influent (before } \\
\text { treatment) }\end{array}$ & $\begin{array}{l}\text { Effluent (after } \\
\text { treatment) }\end{array}$ & & \\
\hline $\mathrm{EC}(\mu \mathrm{S} / \mathrm{cm})$ & $1909.6 \pm 9.3^{\mathrm{a}}$ & $220.6 \pm 1.1^{\mathrm{c}}$ & 88.5 & 1000 \\
\hline TDS (mg/L) & $2565.7 \pm 53.6^{\mathrm{a}}$ & $110.6 \pm 0.6^{\mathrm{c}}$ & 92.0 & 80 \\
\hline TSS (mg/L) & $606.3 \pm 83.3^{\mathrm{a}}$ & $46.7 \pm 5.7^{\mathrm{d}}$ & 92.3 & 50 \\
\hline Turbidity (NTU) & $1049.8 \pm 112^{\mathrm{a}}$ & $529.6 \pm 9^{c}$ & 49.6 & - \\
\hline $\mathrm{pH}$ & $12.62 \pm 0.08^{\mathrm{a}}$ & $8.58 \pm 0.08^{\mathrm{b}}$ & 31.8 & $6-9$ \\
\hline Temperature $\left({ }^{\circ} \mathrm{C}\right)$ & $37.5 \pm 0.79^{\mathrm{a}}$ & $24.9 \pm 0.6^{\mathrm{b}}$ & 33.6 & 40 \\
\hline $\mathrm{COD}(\mathrm{mg} / \mathrm{L})$ & $2565.7 \pm 53.6^{\mathrm{a}}$ & $203 \pm 15.7^{b}$ & 92 & 250 \\
\hline $\mathrm{BOD}_{5}(\mathrm{mg} / \mathrm{L})$ & $1460 \pm 157.6^{\mathrm{a}}$ & $49.8 \pm 17^{\mathrm{b}}$ & 96 & 60 \\
\hline $\mathrm{TN}(\mathrm{mg} / \mathrm{L})$ & $61 \pm 3.9^{\mathrm{a}}$ & $41 \pm 7.23^{\mathrm{b}}$ & 32.8 & 40 \\
\hline $\mathrm{NH}_{4}-\mathrm{N}(\mathrm{mg} / \mathrm{L})$ & $30.9 \pm 7.1^{\mathrm{a}}$ & $17.7 \pm 6.9^{\mathrm{c}}$ & 42.7 & 20 \\
\hline $\mathrm{NO}_{3}-\mathrm{N}$ & $24.8 \pm 1.6^{\mathrm{a}}$ & $19.8 \pm 0.7^{b}$ & 20.2 & $<10$ \\
\hline $\mathrm{NO}_{2}-\mathrm{N}$ & $17.3 \pm 5.3^{\mathrm{a}}$ & $5.5 \pm 1.7^{\mathrm{c}}$ & 68.2 & - \\
\hline $\mathrm{TP}(\mathrm{mg} / \mathrm{L})$ & $34.9 \pm 3.6^{\mathrm{a}}$ & $24.3 \pm 1.4^{\mathrm{b}}$ & 30.4 & 5 \\
\hline $\mathrm{SO}_{4}{ }^{2-}(\mathrm{mg} / \mathrm{L})$ & $6.4 \pm 1.8^{\mathrm{a}}$ & $3.62 \pm 2.1^{\mathrm{b}}$ & 43 & 200 \\
\hline $\mathrm{H}_{2} \mathrm{~S}(\mathrm{mg} / \mathrm{L})$ & $0.6 \pm 0.1^{\mathrm{a}}$ & $3.1 \pm 0.26^{\mathrm{c}}$ & -416.7 & 2 \\
\hline
\end{tabular}

Note: Values with different superscript are significantly different at alpha 0.05 levels

Inorganic nitrogen forms can lead to dissolved oxygen depletion in the receiving water body due to conversion of ammonia to nitrite and then to nitrate. Furthermore, free ammonia form is directly toxic to fish and in nitrate form, it is associated with illnesses such as Methemoglobinemia (Gujeret al., 1995). Moreover, studies have also indicated a possible risk of cancer, as well as the potential to contribute to spontaneous abortions. Nitrates can react with amines or amides in the body to form nitrosamine, which is known to cause cancer (Jasa et.al., 1998).

The removal efficiency for TP was $4.01 \%$ for the influent tank, $2.4 \%$ for equalization tank, $20.2 \%$ for anaerobic tank, $6.9 \%$ for the post-aeration tank, respectively (Table 3), with overall removal efficiency of only $30.4 \%$ (Table 4). Arcadio and Gregoria (2002) noted that insignificant or negligible removal of phosphorous is expected in anaerobic systems and the primary reason for such poor removal in anaerobic processes is that organic phosphorous is hydrolyzed to phosphate, which is not removed by anaerobic processes and consequently, their concentration increases in the liquid phase. The average TP values measured for the final effluent tank was $24.3 \pm 1.4 \mathrm{mg} / \mathrm{L}$ and this concentration is about five-times above EEPA maximum discharge limit of $5 \mathrm{mg} / \mathrm{L}$ (EEA, 20003). The discharge of phosphate salts and detergents used for washing in the brewery is expected to be a regular source of phosphorus. This high value of TP in the effluent indicates that discharging it can cause significant pollution in the receiving water and other forms of environmental damage. However, Marx
(1995) and Teixeira et. al. (2005) indicated that due to organic composition, effluent containing phosphorous will increase the nutrient content and the water retention capacity of soil and thus improve quality of the soils. It may also be applied to recover poor forest soils to improve vegetation cover and soil infiltration capacity.

Very low sulfate removal efficiency was recorded in each treatment units (Table 3). It was expected that significant amount of sulfate would be reduced to sulfide in an anaerobic environment but an excess removal of sulfate did not occur. The reason for this may be due to COD to $\mathrm{SO}_{4}$ ratio of 32.6 which favors methanogens than sulfate reducer bacteria. The concentration of $\mathrm{H}_{2} \mathrm{~S}$ had a mean value of $0.6 \pm 0.1 \mathrm{mg} / \mathrm{L}$ in the influent tank but increased significantly to $3.1 \pm 0.26 \mathrm{mg} / \mathrm{L}$ in the post-aeration tank (Table 4). According to Gerardi (2002), the $\mathrm{H}_{2} \mathrm{~S}$ increase is due to hydrolysis of protein in the wastewater into hydrogen sulfide. The reason for sulfide reduction could be the conversion of sulfide to sulfur by sulfide oxidation under aerobic condition. Furthermore, sulfur can be oxidized to sulfates in the post-aeration treatment tank. This leads to the addition of sulfate, which lowers removal of sulfate from the systems. The low removal of sulfate is not to be a source of environmental concern since the ambient surface water quality standard of Ethiopia for sulfate is 200 $\mathrm{mg} / \mathrm{L}$ and for sulfide $1 \mathrm{mg} / \mathrm{L}$ (EEPA, 2003). 
Throughout the treatment units, the concentrations of $\mathrm{H}_{2} \mathrm{~S}$ (Table 2) has increased indicating poor $\mathrm{H}_{2} \mathrm{~S}$ treatment of the plant. This seems to be due to lack of sufficient hydraulic retention time (HRT) of the effluent in the aeration tank. According to Bosnicet.al. (2000), $\mathrm{H}_{2} \mathrm{~S}$ is a soluble gas and can form weak acids that can cause corrosion and in sewer lines, it can affect structural reinforcements and corrode pipe works. Thus, any discharge to water bodies, even with low concentration can pose toxicological hazards.

The TDS discharge limit set by EEPA (2003) is 80 $\mathrm{mg} / \mathrm{L}$ and the result obtained from the study had mean value $110.6 \pm 0.6 \mathrm{mg} / \mathrm{L}$ (Table 4 ), which is above the limit. The source of high ionic strength and consequent high TDS is expected to be due to chemicals (such as $\mathrm{NaOH}, \mathrm{H}_{2} \mathrm{SO}_{4}, \mathrm{HNO}_{3}, \mathrm{H}_{3} \mathrm{PO}_{4}$ ) used by the factory as a cleaning agent. Even though the overall removal efficiency of TDS is higher $(92.0 \%)$, findings of the present study revealed that the treatment system of Hawassa brewery is not effective enough to bring the concentration below the discharge limit.

Conclusion: Findings of the present study revealed that raw wastewater of the factory had higher values of physicochemical parameters, which were above the national industrial discharge limits. In most cases, the values decreased as the wastewater passed over the treatment units of the plant indicating the involvement of the units in the removal of pollutants, although their efficiencies vary greatly. The study revealed that the values of some nutrient namely: TN, TP, $\mathrm{H}_{2} \mathrm{~S}$ and TDS were higher than the discharge limits indicating the Hawassa St. Gorge brewery waste treatment plant is not effective enough to lower concentrations of these parameters below the discharge limit. If discharged to the surrounding environment directly, some of these nutrients would have an adverse effect on the environment and human health, as the effluent directly joins a stream, river and finally lake Hawassa. Therefore, to make the plant more efficient, the factory must take some technological and technical measures, for example, integrating the UASB treatment system with aerobic fluidized bed reactor. Furthermore, as the treated effluent contains nutrients, it can be recycled for non-potable uses such as irrigation of garden in the factory, etc, which may reduce the amount effluent discharged and reduce the dependence of the factory totally on fresh water supply for all activities. Moreover, the methane-rich biogas from UASB reactor may be used as a fuel for different activities including boiler. Also, the factory should take measures to reduce odor emission, as people living in the surrounding complain bad smell from the effluent. As brewery effluent quality is variable, more similar studies and monitoring should be carried out for the important parameters.

Acknowledgements: We would like to thank BGI Hawassa St. Gorge brewery office and members of management body for financial support and the experts working at WWTP for technical support during the study period. We also would like to acknowledge S/N/N/P Regional Water Resource Bureau for allowing to use their laboratory for analysis.

\section{REFERENCES}

Alebel, A. (2014). Does ISO 14001 accreditation reduces environmental impact of industries: A case study in Addis Ababa, Ethiopia. Open Journal of water pollution and treatment, 1(1): 21-33.

APHA (American Public Health Association).(2005). Standard Methods for the Examination of water and wastewater, 24th Ed., Washington, D. C.

Arcadio, P; Gregoria, A.(2002). Physical-Chemical Treatment of water and wastewater. Morgan State University, Department of Environmental, Baltimore, Maryland.

Bosnic, M; Buljan, J; Daniels R.P. (2000). Pollutants in tannery effluents. Report for United Nations Industrial

Development Organization (UNIDO) US/RAS/92/120, Regional Programme for Pollution Control in the Tanning Industry in South-East Asia, 9 August.

Brewers of Europe. (2002). Guidance Note for Establishing BAT in the Brewing Industry, Brewers of Europe, Brussels. http://www.brewersofeurope.org/asp/publication s/publications.asp

Driessen, W; Vereijken, T;Paques, B. (2003). Recent Developments in Biological Treatment of Brewery Effluent. Institute and Guild of Brewery of Africa Sector. Proceeding 9th Brewing Convention, Victoria Falls, Zambia, Netherlands.

EEPA (Ethiopian Environmental protection Authority). (2003). Guideline Ambient Environment Standards for Ethiopia. Prepared by EPA and UNIDO under ESDI project US/ETH/99/068/ Ethiopia. Addis Ababa.

Enitan, A;Adeyemo, J;Kumari, S; Swalaha, FM;Bux, F. (2015). Characterization of Brewery 
Wastewater Composition International. Journal of Environmental, Chemical, Ecological, Geological and Geophysical Engineering, 9 (9): 1073-1076.

Fatoki, OS;Mathabatha, S. (2001). An assessment of heavy metal pollution in the East London and Port Elizabeth harbours, Water South Africa, 27(2): 233-240

Gerardi, MH. (2002). Nitrification and Denitrification in the activated sludge process. John Wiley and Sons, Inc., New York.

Gerardi, M. (2003). The microbiology of Anaerobic Digesters. Wiley-Inter-science, New Jersey, 5157.

Gujer, W; Hanze, M; Mino, T; Matsuo, T;Wentzel, MC;Marais, GR. (1995). Activated sludge Model No. 2: Biological phosphorus removal. Wat. Sci. Tech. 31(2): 1-11.

Hamer, MJ. (1986). Lab chemical analysis in water and wastewater technology. 2nd Ed. Wiley and Sons. New York. pp 30-46.

Jasa, PJ; Skipton, S; Varner, DL; Hay, D. (1998). G961279 Drinking water: nitrate-nitrogen. Historic materials from University of Nebraska-Lincoln Extension.1424

Kanagachandran, K;Jayaratne, R.(2006). Utilization potential of brewery wastewater, J. Institute of Brewing, 112 (2): 92-96.

Kebena B. (2014). Treatment and Biogas Production Performance Efficiency of St. George Brewery Full Scale Wastewater Treatment System, MSc thesis, Center for Environmental Science, Addis Ababa University, Addis Ababa, Ethiopia.

Larisa, K. (2008). Anaerobic Treatment of Wastewater in a UASB reactor. Licentiate Thesis in Chemical Engineering, Department of Chemical Engineering and Technology. Division of Chemical Engineering, Royal Institute of Technology Stockholm, Sweden.

Marx, DH.(1995). Application of municipal sewage sludge to forest and degraded Land. "Agricultural utilization. Urban and Industrial by-products". ASA, special publication,58, USA.

Sharda, AK; Sharma, MP; Kumar, S. (2013). Performance Evaluation of Brewery Waste Water Treatment Plant. International Journal of Engineering Practical Research (IJEPR), 2 (3): 105- 111 .

Spellman, FR. (2003). Handbook of water and wastewater treatment plant operations.CRC Press LLC.

Sperling, MV. (2007). Wastewater characteristics, treatment and disposal. IWA Publishing.

Stephenson, R;Blackburn, JB.(1998). Industrial Wastewater Systems Handbook. Lewis Publishers, USA.

Teixeira, ST;Melo, WJ;Silva, ET. (2005). Heavy metals in a degraded soil treated with sludge from water treatment plant. Sci. Agric. 62 (5): 498-501

Yared, S. (2008). Biological Nutrient Removal from Brewery Wastewater using a Laboratory Scale Anaerobic/Anoxic/Aerobic Bioprocess. MSc thesis, Center for Environmental Science, Addis Ababa University, Addis Ababa, Ethiopia. 